\title{
Peaceful Co-Existence: A Tool for Sustainable Development Along the Boundary Corridor of Nigeria
}

\author{
Edwin M. C. Izueke, Ph.D \\ eddy.izueke@unn.edu.ng
}

F.C. Okoli, Ph.D

okolfidelis@yahoo.com

Ifeoma I. Nzekwe

Department of Public Administration, University of Nigeria, Nsukka

nzekwe_ify@yahoo.com

\section{Doi:10.5901/mjss.2014.v5n27p364}

\begin{abstract}
This article deals with the relationship between peaceful coexistence and sustainable development. This is against the backdrop of the conflicts that arose as a result of the balkanization of Africa after the Berlin conference, which was done without due regard to traditional boundaries and consanguinity. Political independence provides a window of self-awareness and movements to counter the challenges of the partitioning. These movements manifest in border clashes and betrayals, rather than peace and development. Adopting the Border theory, we theorize that balkanization creates new borders which results in border competition for scarce economic resources or political opportunities that were not there before the partitioning. Land, water and minerals that were hitherto collectively owned before the balkanization became new sources of conflict along the new boundaries. Discourse analysis is the analytical method adopted for the study. We argue that peaceful co-existence rather than movements aimed at correcting the partitioning is a panacea for sustainable development along the boundaries. Specifically peaceful co-existence enhances sustainable development along the boundary corridor.
\end{abstract}

Keywords: sustainable development, peaceful co-existence, boundary corridor, balkanized Africa.

\section{Introduction}

Nigeria was a British colony and shared boundaries with French colonies. However, the manner in which the colonial boundaries were drawn compounded the problems of the colonies. The colonial boundaries did not take into account the ethnic, religious, cultural and geographical lines. Consequently, some culturally, ethnically, and religiously homogenous and contiguous communities were arbitrally severed and forcefully kept in different colonial authorities. And because these communities had been interacting culturally, ethnically, religiously and occupationally before the deluge of imperial occupation, and because the various colonial authorities did not seek integration of the severed communities but, instead their separation, consequent upon the divergent interests of the respective colonial authorities, seeds of discord, disharmony and conflicts were sown in these communities. New boundaries were created and scarce resources became competition objects..

It was not, therefore, surprising that after political independence, when Africans took over the reins of power, the various communities which were suffering under the weight of colonial abuse, consequent upon their "exile" resulting from their forceful separation and excision from their Kiths and Kins, rose up in gallant defense of their "territorial" integrity and "sovereignty". They demanded to be re-integrated with their Kiths and kins wherever they might be in the post independent African countries.

However, the demands and movements rather than help in resolving the conflicts, generated new conflicts. It is our contention that rather than seek for re-integration with kiths the emphasis should be on peaceful co-existence. Needless to say, African countries with greater mix of these colonial anomalies impinging on the free operation and functioning of pre-Berlin Conference ethnic, religious, cultural and spatial identities and sensibilities, faced enormous, in fact, gargantuan development tasks mediated and modulated by the homogeneity or heterogeneity of these critical 
determinants of sustainable development.

Sustainable development entails not only economic development but equitable distribution of economic benefits such as equitable provision of basic needs, remedy of social inequities and environmental damages. It can be achieved only in time of peace.

\section{The Boundary Corridor of Nigeria}

Nigeria (a former British colony) shares boundaries with francophone countries (former French colonies) on all sides. She shares the longest land corridor with Cameroon. The land Corridor with Cameroon stretches for 1, 690 kilometres in the east. The water Corridor, according to Vogt (1987), is the longest and most complicated, topographically, of all Nigeria's international boundaries. This Corridor is very important, indeed, critical to Nigeria's relationship with her neighbour Cameroon. It consists mainly of the Bakassi Peninsular which is located at the South-east end of Nigeria, while the Peninsular flows southward and empties into the Gulf of Guinea. The significance of this Bakassi water Corridor lies in the fact that the Peninsular itself is made up of small Islands of about 50 square kilometers which are inhabited by mostly Nigerians who are fishermen.

It is important to stress the vital point that along the land corridor with Cameroon, the population, religious, cultural and even topographical characteristics of both Nigeria and Cameroon, are similar and predate colonial boundaries, especially around the former Sardauna province in the North. The ethnic, cultural, religious, and occupational activities between Nigerians and Cameroonians along this corridor defy political boundaries and, sometimes, threaten peaceful coexistence between the two countries.

In the North, Nigeria shares boundary with yet another Franco-phone country, Niger. The Nigeria-Niger land corridor spans 1497 kilometers of nearly similar vegetation, topography, religion, ethnic composition and occupations. In the North-east Nigeria shares boundary with the Republic of Chad, another Franco-phone country. The 87 kilometer land corridor, with Chad, although the shortest among the land corridors with other neighbours, is the most restive, volatile and threatening in ethnic, religious, economic and military terms. The similar pastoral activities along and across the border; the ethnic, religious and cultural diffuseness; and the political instability which characterizes Chadian society, have all combined to keep Nigerian and Chadian security agents, on their toes.

In the west, Nigeria shares boundary with the Republic of Benin. This land corridor, which spans 773 kilometers, has tremendous ethnic, cultural, and economic significance for Nigeria. As a result of the colonial boundary imposition, a substantial population of the Yoruba ethnic group is found across the border in Nigeria and Benin Republics. Just as is the case with the Shuwa Arabs, Kanuris and other Hausa-Fulani Communities in Chad, Niger and Cameroon, the Yoruba's of Nigeria move, interact and carryout businesses freely in Republic of Benin. Cotonou, the capital of Benin Republic is, for all practical intents and purposes, an extension of Nigerian ports. For example, at the peak of Nigeria's economic activities leading to unprecedented congestions in the Nigerian ports, Cotonou became a ready alternative and many imports destined to Nigeria found their way through Cotonou port, from where they were transported by land to other parts of Nigeria through "friendly" Yoruba territories. It is, therefore, no wonder that given the nature and distribution of these critical determinants and obstacles to sustainable development efforts along the Nigerian border, the issue of peaceful co-existence takes a centre stage in Nigeria's quest for sustainable development.

\section{Theoretical Perspective}

We adopted Border theory as our framework of analysis According to Fashina (2001) every organ or value in society exists in determinate position to others. And between the thin line of functional divide or interdependency are varieties of exclusive or inclusive borders. It is even probable if cultural, linguistic, social, economic and political borders are not more realistic and intricately problematic in any society than geographical borders. For instance, the pressure of social conflicts than even mere geographical borders constantly plagues every heterogeneous society. The immediate precipitate of the border war between Nigeria and Cameroon is the inclusive and intersectional nature of their shared oil rich Bakassi Peninsula. The cause of economic conflicts between two individuals, corporate bodies or nations is the scarcity of 'borderline' resources. Therefore, in any border competition for 'scarce' economic resources or political opportunities, each competitor strives to dominate the center and push the other to the margins.

In order to apply this theory to the study, we looked at the scarce resources for border competition between Nigeria and her neighbors. The resources are pastoral grazing land, fish and fishing water, oil, and political dominance. These resources have resulted in conflicts along the boundary corridor of Nigeria.

One of the resources for competition is grazing land. There have been frequent clashes between cattle herders 
and host communities, and among themselves. This has happened between Nigeria and Cameroon, Nigeria and Chad, and Nigeria and Niger. These are people that are of common ethnic and religious background before the partitioning. It is important to note that one major source of conflict between Nigerian and Chadian communities revolves around stock routes or what Braukamper (1996) calls "patterns of transhumance of the Shuwa Arab in the Nigeria - Chad Basin".

Other resources that became new source of conflict among hitherto brothers are oil and fishing rights. This is between Nigeria and Cameroon at the Bakassi Peninsular. The competition for these resources resulted in hostilities between the two countries. Economic activities were paralyzed at Bakassi. Eventually the International Court of Justice awarded the Peninsular to Cameroon, which worsened the development activities in the area. Worst still ,the inhabitants were relocated. This happened as a result of the partitioning, before which these people have enjoyed centuries of interaction as people with the same culture, ethnic origin and religious background.

Political opportunity is another major resource for competition between Nigeria and her neighbours. In the quest by the northern part of Nigeria to take over power, a terrorist group known as boko haram (western education is sin) started attacking towns living along the Nigerian borders in the north-east such as Bama,Barga, Kawuri, Alau Fate,etc. From the confessions of those arrested they came from Niger, Chad, Cameroon and Nigeria. These people are of the same religious, cultural and ethnic backgrounds with those they are attacking. With the insurgent on ground no sustainable development could be achieved in any of the places along the boundary corridors of Nigeria and Nigeria in general.

According to Adebayo (2010) in spite of the natural and mineral resources with which the country is endowed, the struggle for political opportunity has made peaceful coexistence elusive among the multi ethno-religious entities which make up Nigeria; the country has virtually become a battle field for ethno-religious crises. There can be no remarkable development that can take place in an atmosphere of crises, chaos and disturbances. Foreign investors would be scared to come. Those displaced or killed will no longer be relevant in the scheme of development.

The apparently intractable phenomenon of Nigeria's porous border manifested in unbridled smuggling activities, leading to tremendous economic losses to Nigeria, frequent clashes between cattle herders and their host communities occasioned by seasonal movements in search of pasture; increased human traffic across the border due primarily to the difficulty in distinguishing between Nigeriens and Nigerians; similarity and interdependence of economic activities; similar religious and cultural practices, has its root in, and is facilitated by, unrealistic post-colonial boundaries

It is important to note here that one major source of conflict between Nigerian and Chadian communities revolves around stock routes or what Braukamper (1996) calls "patterns of transhumance of the Shuwa Arab in the Nigerian-Chad Basin". Stock routes, whether organized or not are routes or ways for livestock movements from one place to another (Hamisu, 2003). Over the years the co-existence between the nomadic herders and sedentary cultivators has given rise to cattle paths for pastoralists to avoid encroachment on cultivated land. This potential for conflict is real and is not limited to internal cattle movements. Cattle movements involve organized activities across the border through what is called international routes. For example, such international routes enter Borno State (Nigeria) from the neigbhouring countries of Niger, Chad and Cameroon Republics (Namadi, 2007).

Considering the communities and local government areas, in Nigeria, covered by this route, and believing that almost the same number of communities may be involved in the Cameroon Republic. The route passes through many communities and local government area in both countries. Considering the number of communities that the route possess it becomes obvious that stock routes are veritable potential sources of conflict among the pastoralists and their host communities, and among the pastoralists and the farmers among the communities across the border, and between Nigeria and the Cameroon Republic (Awognpme, 1981; 1993).

One striking feature of the nomadic Fulani while on transhumance is that they are administered through their leaders who seek permission for grazing and passage from the leadership of the constituted settled authorities. The success of this arrangement depends on mutual cooperation and respect, hence the need for peaceful co-existence. Occasionally, however, conflicts do occur between the pastoralist and the farmers as a result of inadequacy of stock routes for the pastoralist; insufficient grazing lands for the pastoralists, inadequate water points for the livestock; lack of effective grazing reserve policies; increased bush burning; increased population pressure and increased cultivation of crops.

Environmental stress can result from political tension and conflict over the control over raw materials, energy supplies, law, risk, basins, sea passages, and other key environmental resources. Such conflicts are likely to increase as these resources become scarcer and competition for then increase.

The environmental consequences of armed conflict would be most devastating in the case of nuclear war. There are damaging effects too from conventional, biological and chemical weapons, as well as the disruption of economic production and social organization in the wake of warfare and mass migration of refugees. This can be worsened by inadequate development polices, inequality in the development of two neighbouring countries. Environmental refugees 
could be caused by conflicts, deterioration of natural resources and over used or overgrazed lands.

\section{Peaceful Co-Existence}

The notion of peaceful co-existence is, like all such notions in the social sciences, better understood contextually and thematically. Moreover, it lends itself to manipulations and different usages. It is a good servant, indeed, a handy compass, at the control and command of its master. It serves the mighty as well as the weak, the big as well as the small. More importantly, it has been in existence since human settled experiences. In other words, the desire for peaceful existence is part of humanity and has dominated and continued to dominate international, national and local/community efforts at promoting the well-being of the people. For instance, following the political independence of some Asian countries, and their desire to protect and defend their independence, China, India and Myanmar jointly sought solace in peaceful coexistence as a tool for development. Consequently, they issued the five principles of peaceful co-existence as pillars on which to base their developmental aspirations.

The five principles were built around" mutual respect for the sovereignty and territorial integrity of member states; mutual non-interference in each other's internal affairs; equality of members; mutual benefit and peaceful co-existence. The popularity of these principles and their relevance in today's world can be seen from their almost unconditional endorsement by the United Nations in its charter.

It is important to note here that these five principles of peaceful coexistence are not mere rhetoric, they have practical applicability through:

(i) Upholding the sanctity of sovereign equality of states

(ii) Cooperation in the fight against a common problem like terrorism

(iii) Acknowledging with due concern the diversity of world's economies

(iv) Promoting common development of the world's economies on the basis of equality and mutual benefit;

(v) Promotion and maintenance of peace and security through dialogue

(vi) Recognizing and giving full scope to the important role of United Nations and other multilateral arrangements (Chinese Envoy 2007) http://www.empre.en/eng/2xxx/t140777.htm

Consequently, the notion of peaceful co-existence is very crucial and relevant to international development efforts. No wonder the Chinese Envoy proudly asserted that:

Aspiring for peace, development and cooperation has become the popular will of the $21^{\text {st }}$ century and the irresistible tide of the times. Let us hold out hands together, holding high the great banner of the five principles of peaceful co-existence, and make fresh contributions to the lofty cause of world peace and development (http//www.fimpre.en/ eng/2xxx/t140777.htm).

However, while this notion of peaceful co-existence makes enormous sense for the promotion of sustainable development, it falls far short of expectations at the local/community levels. At these levels, co-existence deals with the anxieties and problems which characterize the relationships between persons or groups in which none of the parties is desirous to destroy the other (Kiesberg, 1998). This is exactly the case along Nigeria's border. None of the ethnic, cultural, religious and occupational groups that inhabit both sides of the border is anxious to destroy the other. Rather, what they want is a conducive atmosphere to carry out their businesses. According to Kriesberg (1998) co-existence manifests itself both structurally and subjectively at these levels. Structurally, co-existence is characterized by degrees of interact with each other. It may also be characterized by different degrees of integration or separation between groups. Integrated groups are interdependent and equality and inequality. Along the Nigerian border structural co-existence manifests in the activities of the pastoralists (herdsmen); fishermen, smugglers, and other economic saboteurs, especially in the Lake Chad basin, Bakkasi Peninsular, Cotonou and other centres of illegal economic activities. Because of the interdependent nature of this type of co-existence, efforts to disorganize and dislodge it usually resulted in tension and, sometimes, open conflict.

However, under subjective co-existence identified by Kriesberg (1998), relationships are characterized by degrees of tolerance and mutual respect and, sometimes, dehumanization. Generally, groups tend to value their own members more highly than others, and so to devalue members of other groups. On the whole, tolerance is fostered by identities which cut across group boundaries (Kriesberg, 1998). This is exactly the case along Nigerian border, especially in Bakkasi Peninsular, where centuries of interaction and group activities have engendered tolerance among the inhabitants of both Nigerian and Cameroonian extractions. Unfortunately, this tolerance has been viciously attacked by government security agent, thus leading to threats to peaceful co-existence, or in the Lake Chad zone, where state security agents, including the military, have, on occasions, resorted to military assault on Nigerians. Under these circumstances and depending on the aspects of co-existence being emphasized or frustrated, sustainable development cannot take place. 


\section{Sustainable Development}

The failure of traditional development strategies, which were essentially (top-down), to meaningfully impact positively on the lives of the rural populace, has resulted in the search for, and adoption of an alternative development approach, which applies "bottom-up" strategy to development.

As a concept, sustainable development is that development which meets the needs of the present generation without compromising the ability of future generations to meet their own needs (UNDP Training Module: 17). According to Harris (2000) it is development which protects the environment, advances economic prosperity and social justice. The practical implications of this orientation, is that sustainable development frowns at all activities that degrade or have the potential of degrading the environment, and demands that these activities be stopped. It is, therefore, not surprising that sustainable development is fanatically environment-friendly and advocates and pursues activities and policies that are intended to renew and improve the environment. More importantly, sustainable development preaches, among other things, capacity-building among local beneficiaries of development projects, to ensure that these projects will continue in existence and remain functional even when external assistance is withdrawn or ceases. In this wise, sustainable development cherishes and calls for effective broad participation as a means to sustain the development process, hence the actual meaning of the "bottom-up" approach.

Sustainable development, both as a concept and as a strategy, aims at meeting the country's needs; achieving sustained decent living conditions in a given country, eliminating poverty; maintaining the physical and human environment for the present and future generations of the members of a given country; involving all members of the community in the development process and ensuring equal benefits of what is produced.

Sustainable development pursues the following objectives:

- Economic sustainability-economic growth based on efficient use of resources,

- Environmental sustainability-protection and enhancement of earth resources,

- Social sustainability-through peaceful co-existence and social justice,

- Developing and strengthening good governance at all levels.

In pursuit of these objectives peaceful co-existence is fundamental.

All these efforts can come to naught if there is no peace within and among groups. An attempt at sustainable development without peaceful coexistence is like planting corn on the rock.

\section{Peaceful Co-existence: A Tool for Sustainable Development Along the Boundary Corridor of Nigeria}

We have noted that sustainable development is that development which meets the needs of the present generation without compromising the ability of future generations to meet their own needs. This scenario plays itself out only in conditions of peace and peaceful co-existence. Lack of peace or its converse, a situation of conflict, armed struggle, war and even threats of these, is not and cannot be conducive to development. Crises destabilize human settlements, economic activities, social interactions; conflicts unnecessarily raise tensions and create uncertainties, for instance, among the Nigerian fishermen in the Bakkasi Peninsular, and the Lake Chad; the pastoralists across Nigeria-Niger border; the damming of rivers which pass through neighbouring countries just to punish and spite the target country, as was the case with Nigeria and Cameroon. Apart from all these, conflicts destroy human lives, vital infrastructure, and natural resources.

Peace, on the other hand, promotes development in several ways. Under peaceful conditions people are more at ease and can easily activate their humanity. They can meaningfully think about their present conditions and ways of improving their future. They can be real "rational man", "economic man", "organization man", "and political man". They can invest in economic ventures, participate in social and political activities and think about future generations. Economic activities along the border are beneficial to Nigeria as they add not only to the gross domestic product but also critically affect the development of human capital which is an essential ingredient of sustainable development. These cannot obtain in conditions of crises, conflict or war. The occasional closure of borders by either party normally leads to untold economic and social hardship on both sides.

Instances of the benefits of peaceful co-existence to sustainable development abound. The Kainji Dam, the economic artery of Nigeria, would not have been possible in conditions of conflicts, crises and war between Nigeria and her neigbours- Niger and Benin Republics. Again, the Port of Cotonou, Benin Republic Capital, would not have been accessible to Nigerian businessmen under conditions of crises, war and conflicts. Despite occasional clashes and skirmishes, the fishing rights of Nigerians and Chadians in the Lake Chad would have degenerated into a full-scale war. 
The relative peace and harmony which characterize cattle Fulani transhumance across the border into Niger, Chad and Cameroon, and the opening and sustaining of the stock routes across the border, would not have been possible without peaceful co-existence

\section{Recommendations}

We have seen how conflicts along the boundary corridor of Nigeria have marred efforts at sustainable development. The Nigerian civil war and the recent Islamic insurgence, and the role played by some of Nigerian's neighbours, especially Cameroon, and Benin republic proved to Nigeria that her survival is tied will-nilly to the nature of her relationships with her immediate neighbours. Consequently, peaceful coexistence should be the cardinal objective of Nigeria's foreign policy.

Nigeria should enter into more bilateral and multilateral agreements with her neighbours. For instance, it was observed by Soriwei (2013) it was the cooperation of her neighbours in the fight against Boko Haram (Islamic terrorist group) that brought a major success to the Nigerian government in the fight.

All border related conflicts should be resolved amicably to provide enabling environment for peaceful coexistence, cross border trades, exchanges and good relations. Kimenyi (2012) noted that unless the issue of fully adjudicating a border conflict is resolved, the prospects for peaceful coexistence or sustainable development will be an illusion.

Nigeria should establish or strengthen commissions, agencies and institutes to study and recommend appropriate policies and actions for peaceful coexistence and sustainable development. It is a high priority for Nigeria to embark upon institutional reforms to secure a consensual and productive state, one that can significantly enhance peaceful coexistence of the country's diverse ethnic and religious groups; encourage and promote entrepreneurship, and hence the creation of wealth; and adequately constrain civil servants and politicians so that they do not engage in such growth-inhibiting behaviours as corruption and rent seeking. According to Mbaku (2012) the most critical determinant of poverty and deprivation in Africa has been the absence of institutional arrangements that enhance creation of wealth and also allow ethnic and other groups to live together peacefully.

Ironically, sustainable development is a condition for peaceful co-existence. Hungry and angry people cannot coexist with the rich and the contented. Sustainable development broadens the base of contented citizens through effective economic, social and political participation.

To ensure sustainable development and so peaceful co-existence, governance must be truly democratized. Governance must truly be by the people and for the people. Governance by the people and for the people cannot obtain without liberating the two institutions that are critical in the protection of human rights- the judiciary and the media. It is only when these institutions function as they should that the citizens will self-actualize and begin to see one another as necessary partners and equal partakers of national wealth. At this stage, the cliché may no longer read: peaceful coexistence: A tool for sustainable development but rather, sustainable development: A tool for peaceful co-existence.

\section{References}

Adebayo, R.I.(2010) ethno-Religious Crises and the Challenges of Sustainable Development in Nigeria, in Journal of Sustainable Development in Africa. Vol.12 (4) pp16-27

Awogbode, M.O. (1981): "Livestock Development and Land use in Nigeria." In J. G Galaty et al (eds), The Future of Pastoral People, International Development Centre.

Awogbode, M.O. (1993) The Fulani Pastoralism: A case study of Jos, Zaria. ABU: Zaria Press.

Braukamper, U. (1996) "Strategies of Environmental Adaptation of Agro Pastoral Shuwa Arabs in the Chad Basin". Maiduguri, Nigeria.

Carter, Jimmy (1993) Talking Peace: A Vision for the Next Generation. USA: Puffin Books.

Chinnese Envoy "Carrying forward the five Principles of Peaceful Coexistence in the Promotion of Peace http:/www,fmpregov.cn/eng/zxxx/t140777.htm

Cox, E., L.T. Col. (MBE), (1988) "Chad: France in Africa." The Army Defense and Quarterly Journal, 118(2):161-167.

Ede, O. (1986): "Nigeria and Francophone Africa" (p. 126) in G. Olusanya and R.A. Akindele (eds). Nigeria's External Relations: The first Twenty- Five Years. Ibadan: University Press Itd.

Fashina, N.O. (2001) The centre and the margins: theorizing Nigeria's complex Borders Nigeriaworld http://nigeriaworld.com

Hamisu, A.S. Kano (2003) "Stock and Transhumance Routes: Conflicts and Conflict Resolution, route identification, demarcation and enforcement. A Paper presented at the Pastoral Reserve (PARE) Arewa House

Harris, J.M (2000) Good Governance and Sustainable Development, Global Development and Environmental Institute Working Paper 00-04,June.

James, I. (1987): "The Nigerian-Chadian Boarder Conflict". The Nigerian journal of International Affairs, 10 (1) :63-73.

Kapil, R. (1966) "The Conflict Potential of inherited Boundaries in Africa". World Politics 18(14): (657).

Kimenyi, M. S.(2013)"Future Engagement Between South Sudan and the Republicof Sudan", at http://www.bookings.edu/research/ 
reports/2012/06/south -sudan/egagement

Kolodzieji, E and Harkavy, R. (1982). Security Policies of Developed Countries, U.S. : Lexington Books, Inc.

Kriesberg, Louis. (2007)"Coexistence and the Reconciliation of Communal Conflicts".In, The Handbook of Interethnic Coexistence. New York: Continuum Publishing.

Mbaku, J.M. (2012) Preparing Africa for the Twenty-first Century: strategies for Peaceful Coexistence and Sustainable Development (Contemporary Perspectives on Developing Societies, USA:Asgate Publishers Ltd

Namadi, Buba Gundi A. (2007) "The Administration Nomanic Cattle Rearers in Borno state of Nigeria" A. Ph.D Thesis submitted to the University of Maduguri, (unpublished).

Nwokedi, E. (1984) "The Politics of Inter-African Boundary Conflicts: A study of Nigeria and her Francophone Neighbours" Quarterly Journal of Administration 19 (1 and 2): 85.

Omede, A.J. (2000) Threats and Military Capabilities: A Nigeria Case Study" Ph.D Thesis (Unpublished).

Redclift, Michael. (1994) "Sustainable Development and Popular Participation: A Framework for Analysis". In Grassroots Environmental Action. People's Participation in sustainable Development, Dharam Ghai and Jessica. M. Vivian (eds) London: Routledge 55-78.

Serageldin, Ismail., Michael A., and Leitmann, Josef. (eds) (1994) Enabling Sustainable Community Development World Bank. Washington, D.C.

Soriwei, Fidelis. (2013) "Cameroon troops kill 180 Boko Haram members" - JTF", Punch, October 10

United Nations Development Programme (UNDP) (2006) Training Modules 1-4, Abuja. Ministry of States and Local Government: The Presidency.

UN Documents: Peace, Security, Development, and the Environment. From A/42/427, Our Common Future: Report of the World Commission on Environment and Development: http://www.un.documents.net/oct-11.htm.

Vogt, M.A. (1987) "Strategies for the Enhancement of the Security of Nigerian Boarders". The Engle: Journal of the Nigerian Command and Staff College, Jaji, Nigeria Special Edition: 39-40.

Zartman, J.W. (1965) "The politics of Boundaries in North and West Africa" the Journal of Modern African Studies. 3(2): 120-155 